\title{
Estimate the Prevalence and Pattern of Serious Bacterial Infections (SBIS) in Febrile Young Infants
}

\author{
Rohit Chib ${ }^{1}$, Bharti Bhandari ${ }^{2}$ \\ ${ }^{1,2}$ Department of Pediatrics, Government Medical College Srinagar Kashmir, India
}

\begin{abstract}
Aims and Objectives: To estimate the prevalence and pattern of serious bacterial infections (SBIs) in febrile young infants. Material and Methods: The study was conducted in the Postgraduate Department of Pediatrics, G.B. Pant hospital, an associated hospital of Govt. Medical College Srinagar, which is a referral tertiary care hospital for the children of Kashmir valley. The study was a prospective non-randomized study conducted from April 2011 to March 2012. All infants of age 30-89 days admitted in hospital with rectal temperature $>38 \circ \mathrm{C} / 100.4 \circ \mathrm{F}$ without an apparent focus of infection on history and clinical examination were included in the study. Results: Total of 149 patients fulfilled the inclusion criteria. The prevalence of SBI in our study was $26.2 \%(39$ out of 149 patients were positive for serious bacterial infection). Urinary tract infection in 16 which was $41.0 \%$ (out of 39 SBI's), pneumonia 9 (23.1\%), Occult bacteremia 8 (20.5\%) and bacterial meningitis 6 (15.4\%). Conclusion: Prevalence of 26.2\% of serious bacterial infection in our study was high, as our hospital is a tertiary care, referral centre for sick patients. Urinary tract infection was most common followed by pneumonia, then occult bacteremia and finally bacterial meningitis. Pneumonia in our study was $23.9 \%$ which was quite high, might be because of the fact that study happened at a colder place, which could be a risk factor for more lower airway diseases.
\end{abstract}

Keywords: Serious bacterial infection, Platelets, Fever, Infant, Diagnosis.

\section{Introduction}

Febrile infants less than 3 months of age present a management challenge, as many of these have no identifiable source of fever, and the prevalence of serious bacterial infection (SBI) in this age group is high ${ }^{(1,2)}$. The most commonly suggested strategy is for the febrile neonates to be admitted to a hospital and undergo full sepsis workup. ${ }^{(3-5)}$ In the past decade, several management strategies based on the combination of physical and laboratory findings have been proposed, but no protocol has been universally adopted ${ }^{(6,7)}$. Furthermore, a series of laboratory parameters such as white blood cell (WBC) count, absolute neutrophil count, pyuria, $\mathrm{C}$ - reactive protein (CRP), and more recently, interleukin-6 and procalcitonin, have been extensively evaluated and compared as potential predictors of $\mathrm{SBI}^{(8,9)}$. These laboratory tests lack adequate predictive ability and the idea of a simple, rapid and inexpensive diagnostic test that could accurately identify bacterial infections among febrile infants, remains unattainable ${ }^{(2,4,10)}$. It is not uncommon for infants to suffer from fever within the first 3 months of life. Although such fevers are typically self-limiting, it has been reported that $1-$ $38 \%$ of afflicted infants also have serious bacterial infection $(\mathrm{SBI})^{(1,12)}$. Traditionally, febrile infants younger than 90 days of age were hospitalized, received a full sepsis workup, and were treated with intravenous antibiotics until definitive culture results became available ${ }^{(1,11)}$. Objective was to estimate the prevalence of serious bacterial infection among febrile young infants and pattern of serious bacterial infection (SBI) across the study.

\section{Material \& Methods}

The study was conducted in the postgraduate Department of Pediatrics G.B. Pant hospital, an associated hospital of Govt. Medical College Srinagar, which is a referral tertiary care hospital for the children of Kashmir valley. The study was a prospective non-randomized study conducted from April 2011 to March 2012.

\section{Inclusion Criteria}

All infants of age 30-89 days admitted in hospital with rectal temperature $>38^{\circ} \mathrm{C} / 100.4 \circ \mathrm{F}$ without an apparent focus of infection on history and clinical examination.

\section{Exclusion Criteria}

Infants having fever more than 72 hours, and who had received antibiotics or vaccination within 48 hours of presentation.

\section{Approach}

All patients who had fulfilled, the inclusion criteria, underwent sepsis screening including WBC count, platelet count, blood culture, urine microscopy and culture and CRP. Lumbar puncture for cerebrospinal fluid (CSF) analysis and culture, pleural tap for pleural fluid analysis and culture as well as stool culture and chest radiographs, were obtained at the discretion of the attending pediatrician.

The WBC count with differential and the platelet count were quantified using automated laboratory equipment (Sysmex KX-21). Blood cultures were monitored by an automated system (Bac T/ALERT 3D). Urine was obtained by urethral catheterization using a sterile technique. A careful urinalysis, on a fresh urine sample, can identify children with a high likelihood of UTI to enable presumptive treatment while awaiting results of urine culture, the WBC in the urine were quantified by standard microscopic examination and expressed as WBC $>5$ leukocytes / high power field in a centrifuged sample or $>10$ leukocytes $/ \mathrm{mm}^{3}$ in an uncentrifuged sample ${ }^{(13)}$. The urine, CSF, pleural fluid and stool cultures were monitored using standard laboratory techniques. Normal CSF was defined as, clear in colour, WBCs up to $5 / \mathrm{mm}^{3}$, proteins 10 to $40 \mathrm{mg} / \mathrm{dl}$, glucose content about $60 \%$ of the blood glucose level in a healthy child and 


\section{International Journal of Science and Research (IJSR) \\ ISSN (Online): 2319-7064 \\ Index Copernicus Value (2013): 6.14 | Impact Factor (2014): 5.611}

polymorphonuclear cells were always taken abnormal in all patients ${ }^{(14)}$.

\section{Serious Bacterial Infection}

Was defined as occult bacteremia, urinary tract infection (UTI), bacterial meningitis and pneumonia. Isolates such as Staphylococcus epidermidis in the blood culture were considered contaminants unless they were isolated from more than two consecutive cultures. Urinary tract infection was defined as growth of single known pathogen on urine culture with $\geq 100,000 \mathrm{cfu} / \mathrm{mL}$ of urine obtained by urethral catheterization. Confirmation of the diagnosis on urine culture is necessary ${ }^{(13) .}$ Definite pneumonia was defined as consolidation on chest radiograph plus any of the following signs, a positive blood culture for a pathogenic organism or culture of a pathogenic organism from pleural fluid sample. Probable pneumonia was defined as consolidation alone ${ }^{(15)}$.

Occult bacteremia was defined as a pure growth of a single pathogenic micro-organism on blood culture of a febrile young infant without any apparent focus of infection on history and clinical examination. Probable bacteremia was defined as the growth of two or more types of bacteria ${ }^{(15)}$. Definite bacterial meningitis was defined as isolation of organism on CSF culture. Probable bacterial meningitis was defined as abnormal CSF on analysis with sterile CSF culture $^{(14)}$. Only patient with definite bacterial infection, was taken as serious bacterial infection.

\section{Observation}

Total number of admissions to hospital during the period were 25640. Total number of patients with fever without an apparent focus of infection on history and clinical examination, admitted to hospital was 180 . Total number of patients fulfilling the inclusion criteria was 149.31 patients out of 180 were excluded out of the study, as among these, 12 had fever for more than 72 hours, 3 had received vaccination, 16 were treated with antibiotics within 48 hours of presentation.

Table 1: Showing gender with respect to age:

\begin{tabular}{|c|c|c|c|c|c|c|c|}
\hline \multicolumn{6}{|c|}{ Age and gender distribution of the febrile Patients } \\
\cline { 1 - 7 } Age (day) & Male & Female & \multicolumn{3}{|c|}{ Total } & \multirow{2}{*}{ p value } \\
\cline { 2 - 6 } & $\mathrm{N}$ & $\%$ & $\mathrm{~N}$ & $\%$ & $\mathrm{~N}$ & $\%$ & \\
\hline 30 to 59 & 31 & 41.3 & 39 & 52.7 & 70 & 47.0 & \\
\hline 60 to 89 & 44 & 58.7 & 35 & 47.3 & 79 & 53.0 & \multirow{2}{*}{0.166} \\
\hline Total & 75 & 50.3 & 74 & 49.7 & 149 & 100.0 & \multirow{2}{*}{ (NS) } \\
\hline Median & $66(30,89)$ & $58(30,84)$ & $61(30,89)$ & \\
\hline
\end{tabular}

Total number of males between 30-59 days of age was $41.3 \%$ and females was $52.7 \%$, total number of males between $60-89$ days of age was $58.7 \%$ and females was $47.3 \%$ and Median age of males was 66 $(30,89)$ days and of Females was 58(30,84) days which was non-significant across the study with $P$ value $\geq 0.05$.

Table 2: Showing various investigations across febrile young infants

\begin{tabular}{|c|c|c|}
\hline Variable & Mean & Median \\
\hline Temperature $\mathrm{F}$ & $102.6 \pm 1.1(101,105)$ & 103 \\
\hline Hemoglobin $(\mathrm{gm} \%)$ & $12.0 \pm 2.4(8.6,19.2)$ & 11.6 \\
\hline $\begin{array}{c}\text { Total Leucocyte } \\
\text { Count (000's) }\end{array}$ & $12079 \pm 5039(5200,29000)$ & 11000 \\
\hline DLC_P\% & $50.6 \pm 17.7(19,82)$ & 50 \\
\hline DLC_L\% & $43.6 \pm 17.3(15,80)$ & 45 \\
\hline DLC_M\% & $5.7 \pm 5.3(0,25)$ & 5 \\
\hline $\begin{array}{c}\text { Platelet Count } \\
\left(\text { lakh) } / \mathrm{mm}^{3}\right.\end{array}$ & $4.2 \pm 1.5(0.4,7.5)$ & 4.3 \\
\hline
\end{tabular}

This table shows mean, $\pm 1 \mathrm{SD}$, lowest and highest values of each investigation and median across febrile young infants.

Mean $\pm 1 \mathrm{SD}$ of temperature $\circ \mathrm{F}$ was $102.6 \circ \mathrm{F} \pm 1.1$, Hemoglobin $12.0 \pm 2.4$, Total Leucocyte Count 12079 \pm 5039 and Platelet count $4.2 \mathrm{lakh} / \mathrm{mm}^{3} \pm 1.5$ across febrile young infants .

Table 3: Depicting investigations across Febrile Young Infants

\begin{tabular}{|c|c|c|c|}
\hline & Investigation & $N$ & $\%$ \\
\hline \multicolumn{2}{|l|}{ Thrombocytosis $>41 \mathrm{lakh} / \mathrm{mm} 3$} & 93 & 62.4 \\
\hline \multicolumn{2}{|l|}{ TLC $\geq 15000 / \mathrm{mm} 3$} & 44 & 29.5 \\
\hline \multicolumn{2}{|l|}{ C-Reactive Protein $\geq 2 \mathrm{mg} / \mathrm{dl}$} & 35 & 23.5 \\
\hline \multirow{5}{*}{ Blood Culture } & Sterile & 140 & 94.0 \\
\hline & Escherichia Coli & 1 & 0.7 \\
\hline & Klebsiella & 2 & 1.3 \\
\hline & Methicillin Resistant Staphaureus & 3 & 2.0 \\
\hline & Staphylococcus Aureus & 3 & 2.0 \\
\hline \multirow{2}{*}{ Urine Examination for Pus Cells } & $>5$ & 31 & 20.8 \\
\hline & $\leq 5$ & 118 & 79.2 \\
\hline \multirow{3}{*}{ Urine Culture } & Sterile & 133 & 89.3 \\
\hline & Escherichia Coli & 11 & 7.4 \\
\hline & Klebsiella & 5 & 3.4 \\
\hline CXR for Pneumonia & $+\mathrm{Ve}$ & 9 & 6.0 \\
\hline Pleural Fluid culture & $+\mathrm{Ve}$ & 9 & 6.0 \\
\hline \multirow{3}{*}{ CSF Analysis } & Abnormal & 6 & 4.0 \\
\hline & Normal & 99 & 66.4 \\
\hline & Not done & 44 & 29.5 \\
\hline \multirow{4}{*}{ CSF Culture $(\mathrm{n}=105)$} & Sterile & 99 & 94.3 \\
\hline & Group B Streptococcus & 2 & 1.9 \\
\hline & Escherichia Coli & 2 & 1.9 \\
\hline & Methicilline Resistant Staphylococcus aureus & 2 & 1.9 \\
\hline Stool culture & $+\mathrm{Ve}$ & 0 & 0.0 \\
\hline
\end{tabular}




\section{International Journal of Science and Research (IJSR) \\ ISSN (Online): 2319-7064 \\ Index Copernicus Value (2013): 6.14 | Impact Factor (2014): 5.611}

Thrombocytosis $>4 \mathrm{lakh} / \mathrm{mm}^{3}$ was positive in $93(62.4 \%)$, TLC $\geq 15000 / \mathrm{mm} 3$ in 44 (29.5\%), C-Reactive Protein $\geq 2 \mathrm{mg}$ /dl was in $35(23.5 \%)$, Blood Culture in $9(6 \%)$, Urine Examination for Pus Cells $>5$ cells in $31(20.8 \%)$, Urine Culture $16(10.7 \%)$, CXR for Bacterial Pneumonia and Pleural Fluid Analysis / culture for separation of pathogen responsible for bacterial pneumonia were in $9(6 \%)$, CSF
Culture was positive in $6(4 \%)$ and Stool culture was positive in nil, in one patient Escherichia Coli was isolated in both urine culture and blood culture, three contaminated blood cultures of Staphylococcus epidermdis were also noted. There was no case of bacterial pneumonia positive for blood culture.

Table 4: Depicting the final diagnosis labeled to patients.

\begin{tabular}{|c|c|c|}
\hline Diagnosis & $\mathrm{N}$ & $\%$ \\
\hline Pneumonia & 3 & 2.0 \\
\hline Non Bacterial Enteritis & 21 & 14.1 \\
\hline Bronchiolitis & 41 & 27.5 \\
\hline Bacterial Meningitis & 4 & 2.7 \\
\hline Occult Bacteremia & 8 & 5.4 \\
\hline Environmental Hyperthermia & 3 & 2.0 \\
\hline Hydronephrosis with Urinary Tract Infection & 1 & 0.7 \\
\hline Faulty Feeding with Pneumonia & 2 & 1.3 \\
\hline Faulty Feeding with Bacterial Meningitis & 2 & 1.3 \\
\hline Downs Syndrome with TGA with Bronchiolitis & 2 & 1.3 \\
\hline Moderate Pulmonary Artery Hypertension with TR & & \\
with Bronchiolitis & 1 & 0.7 \\
\hline Cerebral Palsy with Pneumonia & 2 & 1.3 \\
\hline Acute Viral Exanthem & 37 & 24.8 \\
\hline Urinary Tract Infection with Occult Bacteremia & 1 & 0.7 \\
\hline Faulty Feeding with Acute Viral Exanthem & 3 & 2.0 \\
\hline Spino-muscular Atrophy with Pneumonia & 2 & 1.3 \\
\hline Urinary Tract Infection & 14 & 9.4 \\
\hline Downs Syndrome with Bronchiolitis & 2 & 1.3 \\
\hline
\end{tabular}

Table 5: Depicting infectious causes of illness in febrile young infants

\begin{tabular}{|l|c|}
\hline \multicolumn{1}{|c|}{ Final diagnosis } & $\%$ \\
\hline Bronchiolitis & 30.9 \\
\hline Acute Viral Exanthem & 26.8 \\
\hline Non Bacterial Enteritis & 14.1 \\
\hline Urinary Tract Infection & 10.7 \\
\hline Pneumonia & 6.0 \\
\hline Occult Bacteremia & 5.5 \\
\hline Bacterial Meningitis & 4.0 \\
\hline Environmental Hyperthermia & 2.0 \\
\hline
\end{tabular}

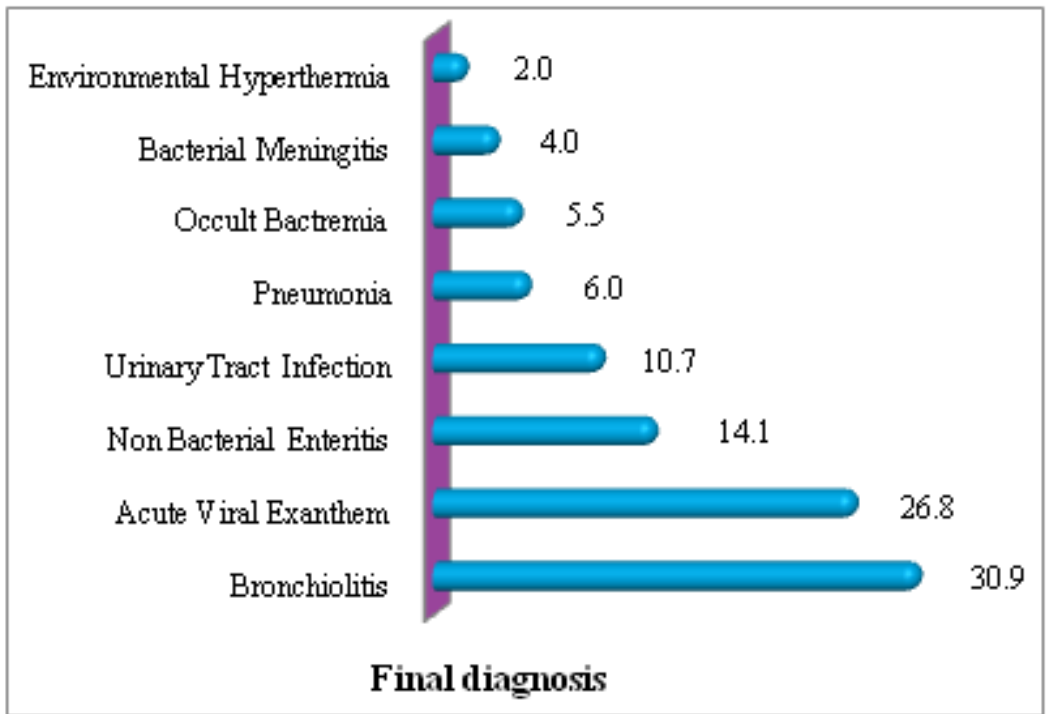

Graph 1: Depicting infectious causes of illness in febrile young infants 


\section{International Journal of Science and Research (IJSR) \\ ISSN (Online): 2319-7064}

Index Copernicus Value (2013): 6.14 | Impact Factor (2014): 5.611

Table 6: Showing total SBI and Non-SBI across study

\begin{tabular}{|c|c|c|}
\hline SBI & N & \% \\
\hline Present & 39 & 26.2 \\
\hline Absent & 110 & 73.8 \\
\hline
\end{tabular}

Table 7: Depicting serious bacterial infection in febrile young infants

\begin{tabular}{|c|c|}
\hline Final diagnosis & $\%$ \\
\hline Urinary Tract Infection & 10.7 \\
\hline Pneumonia & 6.0 \\
\hline Occult Bacteremia & 5.5 \\
\hline Bacterial Meningitis & 4.0 \\
\hline Non-SBI & 73.8 \\
\hline
\end{tabular}

Table 8: Depicting serious bacterial infection across diagnosis.

\begin{tabular}{|l|c|}
\hline Serious Bacterial Infection across Diagnosis & $\%$ \\
\hline Pneumonia & 23.1 \\
\hline Meningitis & 15.4 \\
\hline Occult Bacteremia & 20.5 \\
\hline Urinary Tract Infection & 41.0 \\
\hline
\end{tabular}

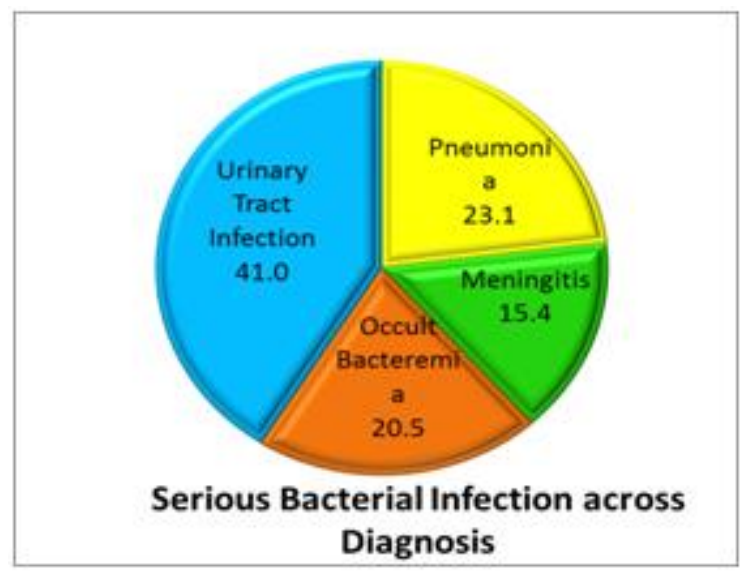

Graph 2: Depicting serious bacterial infection across diagnosis

Table 9: Comparing investigations across SBI and Non-SBI (MRSA: Methicillin-resistant Staphylococcus aureus; E.Coli : Escherichia Coli )

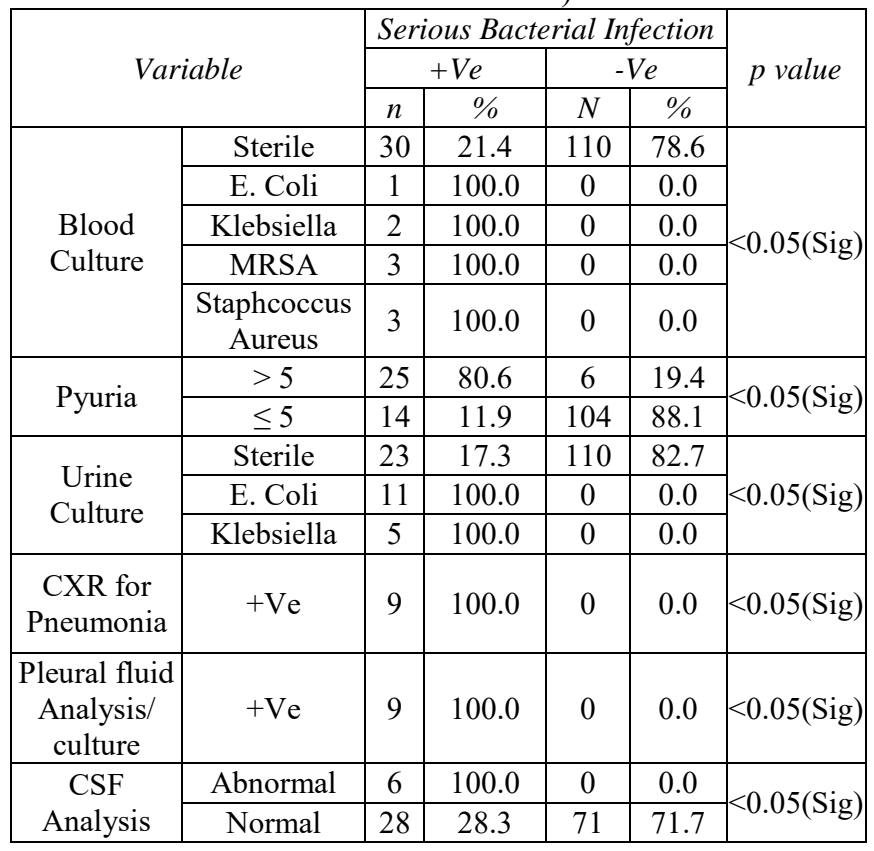

\begin{tabular}{|c|c|c|c|c|c|c|} 
& Not done & 5 & 11.4 & 39 & 88.6 & \\
\hline \multirow{5}{*}{ CSF Culture } & Sterile & 28 & 28.3 & 71 & 71.7 & \\
\cline { 2 - 7 } & $\begin{array}{c}\text { Group B } \\
\text { Streptococcus }\end{array}$ & 2 & 100.0 & 0 & 0.0 & \multirow{1}{*}{$<0.05$ (Sig) } \\
\cline { 2 - 7 } & E. Coli & 2 & 100.0 & 0 & 0.0 & \\
\cline { 2 - 7 } & MRSA & 2 & 100.0 & 0 & 0.0 & \\
\hline
\end{tabular}

Blood culture was positive in 9 SBI patients, urine culture 16 , CSF culture 6 , chest X-ray suggestive of bacterial pneumonia and Pleural fluid analysis /culture for isolation of pathogen responsible for bacterial pneumonia in 9 .

\section{Discussion}

Total number of patients fulfilling the inclusion criteria were 149. The prevalence of SBI in our study was $26.2 \%$ (39 out of 149 patients were positive for serious bacterial infection), Allen L. Hsiao et al. ${ }^{(2)}$ studied 429 infants out of which 44 $(10.3 \%)$ patients were diagnosed with serious bacterial infection, in another study Pulliam PN et al. ${ }^{(16)}$ studied seventy-seven patients and they enrolled SBI in $18 \%$ of the patients and Annick Galetto-Lacour et al. ${ }^{(17)}$ studied 99 patients and noticed serious bacterial infection in $29 \%$. Prevalence of SBI was quite high in our study which was conducted at a tertiary care, referral centre, to which more sick patients are referred, so this can be the reason for high prevalence of SBI in our study. The total number of males in this study was $75(50.3 \%)$ and females $74(49.7 \%)$,SBI was reported in $20(26.7 \%)$ males and $19(25.7 \%)$ females, $P$ value $>0.05$, so gender by itself was not a risk factor for SBI , another study by Allen L. Hsiao et al. ${ }^{(2)}$ studied that gender distribution among SBI, of 218 male infants , 23 $(10.6 \%)$ had SBI compared with $21(10.0 \%)$ of 211 female infants, this study also showed no gender bias. All 149 patients $30-89$ days old were divided into two age groups 30-59 days old and $60-89$ days old, there were 23 patients in SBI and 47 in Non-SBI of 30-59 days age, and 16 in SBI and 63 of Non-SBI of $60-89$ days age. There was almost equal distribution of the patients, of 30-59 and 60-89 days of age across SBI, so SBI was independent of age groups across study, $\mathrm{P}$ value $>0.05$, another study conducted by Allen L. Hsiao et al. ${ }^{(2)}$ showed that the youngest infants in the study, 57-89 days of age, were not statistically significant more likely to have SBI compared with the oldest infants, who were $150-179$ days of age ( $8.8 \%$ vs $12.9 \%)$, and were no more likely than those aged 120-149 days.

Total number of SBI in our study was 39 (26.2\%) out of 149 studied patients. Urinary tract infection in 16 , which was $41.0 \%$ (out of 39 SBI's), pneumonia 9(23.1\%), Occult bacteremia $8(20.5 \%)$ and bacterial meningitis $6(15.4 \%)$. Urinary tract infection was most common followed by pneumonia, then occult bacteremia and finally bacterial meningitis , another study conducted by S Fouozas et al. ${ }^{(18)}$ had also shown urinary tract infection as the most common SBI with $88(85.4 \%)$ out of 103 followed by occult bacteremia $9(8.7 \%)$ then pneumonia $6(5.8 \%)$ and bacterial meningitis $2(1.9 \%)$.

In this study total number of SBI with urinary tract infection was $16(41.02 \%)$ Escherichia coli was positive in 11 ( $68.8 \%$ ) and klebsiella in $5(31.2 \%)$, study conducted by $\mathrm{S}$ Fouozas et al. ${ }^{(18)}$ had also shown Escherichia coli as the 


\section{International Journal of Science and Research (IJSR) \\ ISSN (Online): 2319-7064 \\ Index Copernicus Value (2013): 6.14 | Impact Factor (2014): 5.611}

major pathogen responsible for urinary tract infection, 74 patients out of 88 ( $84.1 \%$ patients). In our study 16 patients had urinary tract infection (out of $39 \mathrm{SBI}$ ), 9 (56\%) were males and $7(43.8 \%)$ patients were females, so urinary tract infection was more common in males than in females also, all the male patients in our study were uncircumcised, in another study by Allen L. Hsiao et al. ${ }^{(2)}$ they noticed that of the 217 male infants with urine cultures, circumcision status was recorded in 178 . Fifty $(28.1 \%)$ were uncircumcised, whereas $128 \quad(71.9 \%)$ were circumcised. Of the uncircumcised males, $36 \%$ had bacteruria compared with $1.6 \%$ of the circumcised males, which was statistically significant ( $p$ value $<0.05$ ). There was 1 case of bacteruria among the male infants of undocumented circumcision status. He also noticed bacteruria only in $9.7 \%$ of female infants, meaning that urinary tract infection was more common in males than in females and that too in uncircumcised males, so the results of this study were in concurrence to that of our's. Incidence of pneumonia in our study was $23.9 \%$ (9 out of $39 \mathrm{SBI}$ ), which was quite high in comparison to another study by S Fouozas et al. ${ }^{(18)}$ in which incidence was $5.8 \%$ (6 out of $103 \mathrm{SBI}$ ), high incidence in our study could be because of the topographic features of the place of study.

\section{Conclusion}

Total number of patients fulfilling the inclusion criteria was 149. The prevalence of SBI in our study was $26.2 \%$ (39 out of 149 patients were positive for serious bacterial infection). SBI was independent of age, gender and residence, $P$ value insignificant. Urinary tract infections were most common $41.0 \%$ followed by pneumonia $23.1 \%$, then occult bacteremia $20.5 \%$ and finally bacterial meningitis $15.3 \%$. E. coli was most common pathogen for UTI, positive in $68.8 \%$. UTI was more common in males $56 \%$ versus females $43.8 \%$. Incidence of pneumonia in our study was $23.9 \%$ which was quite high, might be because of the fact that study happened at a colder place, which could be a risk factor for more lower airway diseases.

\section{References}

[1] Baraff LJ, Oslund SA, Schriger DL, Stephen ML. Probability of bacterial infections in febrile infants less than three months of age: a metaanalysis. Pediatr Infect Dis J 1992; 11: 257-264

[2] Hsiao AL, Chen L, Baker MD. Incidence and predictors of serious bacterial infection among 57- to 180-day-old infants. Pediatrics 2006; 117: 1695- 1701.

[3] Baker MD, Avner JR, Bell LM. Failure of infant observation scales in detecting serious illness in febrile, 4- to 8- week-old infants. Pediatrics 1990; 85: 10401043. 4. Steere M, Sharieff GQ, Stenklyft PH. Fever in children less than 36 months of age - Questions and strategies for management in the emergency department. J Emerg Med 2003; 25: 149-157.

[4] Ishimine P. Fever without source in Children 0 to 36 months of age. Pediatr Clin North Am 2006; 53: 167194.

[5] Baraff LJ, Bass JW, Fleisher GR, Klein JO, McCracken $\mathrm{GH} \mathrm{Jr}$, Powell KR, et al. Practice guideline for the management of infants and children 0 to 36 months of age with fever without a source. Pediatrics 1993; 92: 112.

[6] Jaskiewicz JA, McCarthy CA, Richardson AC, White $\mathrm{KC}$, Fisher DJ, Dagan $\mathrm{R}$, et al. Febrile Infant Collaborative Study Group. Febrile infants at low risk for serious bacterial infection - an appraisal of the Rochester criteria and implications for management. Pediatrics 1994; 94: 390-396.

[7] Bachur RG, Harper MB. Predictive model for serious bacterial infections among infants younger than 3 months of age. Pediatrics 2001; 108: 311- 316.

[8] Olaciregui I, Hernández U, Muñoz JA, Emparanza JI, Landa JJ. Markers that predict serious bacterial infection in infants under 3 months of age presenting with fever of unknown origin. Arch Dis Child 2009; 94: 501-505.

[9] Hsiao AL, Baker MD. Fever in the new millennium: a review of recent studies of markers of serious bacterial infection in febrile children. Curr Opin Pediatr 2005; 17: $56-61$

[10] McCarthy PL. Infants with fever. N Engl J Med 1993;329: 1493-4.

[11]Bonsu BK, Chb M, Harper MB. Identifying febrile young infants with bacteremia: is the peripheral white blood cell count an accurate screen? Ann Emerg Med 2003;42:216-25.

[12] Consensus Statement on Management of Urinary Tract Infections. Indain Pediatrics 2001;38: 1106-1115

[13] Nelson Textbook of Pediatrics, 20/E, Vol.2 ;603:29362948.

[14] Jonathan C Craig, Gabrielle J Williams, Mike Jones, et al. The accuracy of clinical symptoms and signs for the diagnosis of serious bacterial infection in young febrile children: prospective cohort study of 15781 febrile illnesses BMJ. 2010; 340: c1594.

[15] Pulliam PN, Attia MW, Cronan KM. C-reactive protein in febrile children 1 to 36 months of age with clinically undetectable serious bacterial infection. Pediatrics 2001; $108 ; 1275-1279$.

[16] Galetto-Lacour A, Zamora SA, Gervaix A. Bedside procalcitonin and C-reactive protein tests in children with fever without localizing signs of infection seen in a referral center. Pediatrics 2003; 112; 1054-1060.

[17]S Fouozas , L Mantagou, E Skylogianni and Varvarigou. Reactive Thrombocytosis in Febrile Young Infants with Serious Bacterial Infection From the Department of Pediatrics, University Hospital of Patras, Patras, Greece.Indian Pediatr 2010;47:937-94 